\section{Heart rate and energy expenditure during garbage collection in Rio de Janeiro, Brazil}

\author{
Freqüência cardíaca e gasto energético durante a \\ coleta de lixo domiciliar no Rio de Janeiro, Brasil
}

\author{
${ }^{1}$ Departamento de Nutrição \\ Social, Universidade Federal \\ Fluminense, Niterói, Brasil. \\ 2 Escola Nacional de Saúde \\ Pública Sergio Arouca, \\ Fundação Oswaldo Cruz, \\ Rio de Janeiro, Brasil. \\ ${ }^{3}$ Faculdade de Engenharia, \\ Universidade do Estado do \\ Rio de Janeiro, Rio de Janeiro, \\ Brasil. \\ 4 Instituto de Nutrição, \\ Universidade do Estado do \\ Rio de Janeiro, Rio de Janeiro, \\ Brasil. \\ Correspondence \\ L. A. Anjos \\ Centro de Estudos da Saúde \\ do Trabalhador e Ecologia \\ Humana, Escola Nacional de \\ Saúde Pública Sergio Arouca, \\ Fundação Oswaldo Cruz. \\ Rua Leopoldo Bulhões 1480, \\ Rio de Janeiro, $R J$ \\ 21041-210, Brasil. \\ anjos@ensp.fiocruz.br
}

\begin{abstract}
Physiological workload is used to estimate the physical demand of tasks in the workforce, but limited information is available for the various work activities in developing countries. Eightythree randomly selected male workers participated in the present study, aimed at assessing the physiological workload of garbage collection (GC) in Rio de Janeiro, Brazil. Heart rate (HR) was obtained on four consecutive workdays. Energy expenditure (EE) was extrapolated from heart rate data based on individual laboratoryestablished heart rateloxygen consumption curve in 70 workers. Mean HR during GC was $104.0 \pm$ $11.7 \mathrm{bpm}( \pm S D)$, representing $56.9 \pm 7.5 \%$ of maximum heart rate. EE was $1608.3 \pm 738.5 \mathrm{kcal}$ for an average of $293.1 \pm 103.9$ minutes of work per day. Based on all measurements, work in garbage collection in Rio de Janeiro can be considered excessively heavy. These data emphasize the need to develop appropriate classification of workload to be used in health-related research and in the development of maximum acceptable work time in association with the physiological workload, particularly in developing countries.
\end{abstract}

Energy Metabolism; Workload; Workers; Solid Waste Collection
Luiz A. Anjos 1,2

João A. Ferreira 3

Jorginete J. Damião 4

\section{Introduction}

Garbage collection is an essential public service with a large workforce. It is estimated that 90,000 workers are employed in domestic garbage collection in Brazil. In the city of Rio de Janeiro, a total of approximately 5,000 tons of household garbage is collected daily. In general, the job varies according to local technological development, geographic characteristics, and the population's culture and education 1 . For the workers, the job involves walking and running up and downhill and lifting variable-weight loads all day long 2, during which time the worker is under constant stress because of traffic ${ }^{3}$ and in many cases a lack of tolerance by pedestrians.

Assessment of energy expenditure during work and its physical demand is important for the fields of work physiology and workers' health, because it provides useful information for determining the job's physiological workload 4 and estimating the workers' energy requirements 5 . The expenditure values for various jobs according to the Brazilian legislation fail to account for individual characteristics, technological development, and work organization and were derived from currently outdated studies conducted elsewhere in the world 6 . It is thus necessary to specifically assess the physiological response to work in the Brazilian workforce in an effort to document the appropriate relationship between maximum acceptable work time and physiologi- 
cal workload 7,8,9. The present study reports the physiological assessment of domestic garbage collection conducted in the field, in a probabilistic sample of workers from the Municipal Solid Waste Management Utility Company in the city of Rio de Janeiro, Brazil.

\section{Materials and methods}

Standard operational garbage collection crews in Rio de Janeiro consist of 4 male workers who gather and throw the garbage deposited along curbside into the garbage truck. Each team has its own routes, which are repeated every other day (one route on Mondays, Wednesdays, and Fridays and the other on Tuesdays, Thursdays, and Saturdays). Workers are only free to go home after completing their daily route, no matter how long it takes. Daily routes are planned not to exceed eight hours, and in most cases they are completed in no more than seven hours.

\section{Subjects}

The sample size for the study (approximately 80) was established based on heart rate (HR) values obtained in a pilot study. From a list of all male workers involved in daytime garbage collection provided by the Municipal Solid Waste Management Utility Company ( $\mathrm{n}=503$ ), 166 workers were randomly selected and invited to participate in the study. This number was used because it was anticipated that a large number of individuals might not be interested in participating or would be unavailable. Since the morning shift had the largest contingent of subjects in the company, it was decided to invite only daytime workers. Therefore, the primary sampling unit was the selected worker in a simple randomized design.

\section{Procedures}

Data collection took place from June to November 1996 and occurred in three stages, comprising field and laboratory components. The 166 selected workers were invited to appear at the laboratory on a specific day and time. Only 126 workers accepted the invitation and participated in the first stage of the study, consisting of obtaining anthropometric measurements (body mass - BM, stature, and body mass index - BMI $=$ BM.stature -2 ) and socioeconomic, dietary, health, and physical activity characteristics. Subjects signed an informed consent form at this appointment. All procedures were approved by the Research Ethics Committee of the Oswaldo Cruz Foundation (FIOCRUZ), Rio de Janeiro.
The second stage consisted of HR monitoring during work shifts on 4 consecutive days (Monday through Thursday) for all workers participating in the first stage. Due to equipment malfunctioning, absence, refusal, worker unit, and shift transfer and other changes in labor organization it was possible to monitor 83 workers on a total of 314 worker-days. HR was monitored by telemetry using POLAR Vantage NV monitors (Polar Electro Oy, Finland), which were placed on subjects early in the morning before the truck left the worker's unit and removed upon their return at the end of the daily work routine. The units were coded so that it was possible to monitor more than one worker in a team. Information on time of truck departures and arrivals and breaks for truck unloading were obtained from the daily log filled out by the truck driver. It was thus possible to calculate total daily working hours (TWH), that is, the time elapsed between departure from and return to the unit and the daily time of garbage collection (TGC), calculated as TWH minus haul time. Calculation of these two times is important because theoretically workers' activity can vary while trucks are unloading: some rest, while others prepare the garbage for collection while waiting for the truck to return.

The third stage consisted of measuring resting energy expenditure and performing a submaximal walking treadmill test. Only 70 of the 83 workers whose HR had been monitored came to the laboratory for these measurements. Resting energy expenditure (EE) was measured by indirect calorimetry (Aerosport TEEM 100, INBRASPORT, Porto Alegre, Brazil) in which ventilation, $\mathrm{O}_{2}$ consumption $\left(\mathrm{V}_{\mathrm{O}_{2}}\right)$, and $\mathrm{CO}_{2}$ production $\left(\mathrm{V}_{\mathrm{CO}_{2}}\right)$ minute values were obtained 10 . Workers were instructed to fast for 12 hours and to appear at the laboratory around 7:00 AM. Upon arrival, they rested for 30 minutes in a darkquiet room with ambient temperature kept at around $25^{\circ} \mathrm{C}$. After this rest period, HR and gas exchange were measured for 25 minutes with the worker lying down, then 5 minutes sitting and 5 minutes standing. Minute resting EE was calculated using Weir's equation 11 and expressed in kcal using the last 20 minutes the subject was supine.

A sub-maximal walking treadmill test was conducted to obtain an individual calibration curve based on the relationship between HR and EE. It included 3-minute stages with initial speed of $2.5 \mathrm{mph}$ and $0 \%$ slope followed by an increase in speed to $3.5 \mathrm{mph}$ and maintenance of this speed with elevation of $2.5 \%$ for each subsequent stage (up to $10 \%$ ). The test ended after 18 minutes (3.5mph and $10 \%$ ); upon request of the subject or if HR reached $60 \%$ of reserve HR $\left(\% \mathrm{HR}_{\text {res }}=\left\{\mathrm{HR}-\mathrm{HR}_{\text {resting }} /\left[(220\right.\right.\right.$-age $\left.\left.)-\mathrm{HR}_{\text {resting }}\right]\right\} \mathrm{x}$ 
100). $\mathrm{HR}_{\text {resting }}$ was established as the mean heart rate value during resting EE measurement (last 20 minutes).

\section{Measurements and statistical analysis}

Working HR (stage two) was expressed both in absolute values and relative to individual maximum (220-age) and $\mathrm{HR}_{\text {res }}$ daily ( $\mathrm{n}=314$ days) in all 83 workers. Energy expenditure was estimated using the Flex heart rate method 12 in 266 days of all 70 workers for whom the heart rate-energy expenditure relationship was obtained during the walking treadmill test (calibration curve). The method consists of determining the critical HR (Flex) which is equal to the mean of the highest resting and the lowest walking HR values, to which $10 \mathrm{bpm}$ is added (FlexHR +10$)$. For all working heart rates below this value, EE is assumed to be the mean value for lying (resting EE), sitting, and standing. When HR is higher than the FlexHR + 10 value, EE is estimated from the regression equation individually calculated during the walking calibration curve. This method has been validated against other more sophisticated methods of energy expenditure measurement such as doubly labeled water and direct calorimetry and is recognized as a feasible method to be used in epidemiological studies 13 .

EE during TWR and TGC was calculated by adding energy expenditure for all minutes of the respective periods and expressing the result in absolute values ( $\mathrm{kcal}$ ) and relative to resting $\mathrm{EE}$, a ratio that is called integrated energy index (IEI) 5,14 and is used along with $\mathrm{HR}_{\text {res }}$ to determine the workload intensity.

Some data were not obtained for all workers, so the number of subjects and monitored days are thus presented in the tables. Statistical analysis included comparison of working hours and physiological variables on workdays using ANOVA one-way and Tukey 15 for the differences between means for the significant variables $(p<0.05)$ using SAS version for microcomputer (SAS Inst., Cary, U.S.A.). Pearson correlation coefficients were calculated between TGC and workload (IEI).

\section{Results}

Mean age of workers was $36.8 \pm 8.0$ years (mean $\pm \mathrm{SD}$ ) and varied from 19.7 to 63.0 years. Mean body mass was $67.7 \pm 11.0 \mathrm{~kg}$ and mean stature $171.8 \pm 6.3 \mathrm{~cm}$, representing a mean BMI of 22.9 $\pm 3.2 \mathrm{~kg} . \mathrm{m}^{-2}$ (Table 1 ).

Heart rate information was obtained for a total of 153,584 minutes (approximately 2,560 hours) in the 83 workers on 314 days, with an average daily TWH of $489.1 \pm 171.6$ minutes.day ${ }^{-1}$ (approximately eight working hours/day, Table 2). Daily TGC totaled 90,284 minutes and varied from 76 to 578 minutes ( $\cong 1$ to 9.6 hours) with an average of $293.1 \pm 103.9$ minutes, approximately 5 hours per day of actual garbage collection working time (Table 3). Neither absolute HR nor $\% \mathrm{HR}_{\max }$ differed between subjects who completed all the procedures $(n=70)$ and those in whom the metabolic measurements were not taken $(n=13)$.

There was no significant difference in TWH or TGC comparing Mondays and Tuesdays or Wednesdays and Thursdays, but both were significantly shorter in the latter two days. Minute HR and EE did not differ significantly among days. Since working time was longer on Mondays and Tuesdays, total daily EE was significantly higher on these days in both TWH and TGC.

There was no significant difference among the days of the week in terms of work intensity, which on average was greater than $50 \%$ of maximum heart rate $\left(\% \mathrm{HR}_{\max }\right)$ and $30 \%$ of reserve heart rate $\left(\% \mathrm{HR}_{\mathrm{res}}\right)$. Expressed as a multiple of resting metabolic rate $($ IEI $=E E / R M R)$, the value was greater than 5 for TGC (Table 3 ) and slightly lower for TWH (Table 2). There was no relationship between time worked and workload (Figure 1).

\section{Discussion}

The work process in household garbage collection exposes garbage workers to various risks 16, thus aggravating its exhaustive intensity 1 . Brazilian legislation classifies garbage collection as one of the unhealthiest jobs because of exposure to biological agents 17 . The physiological workload data from the current study also document the extreme intensity of physical exertion in garbage collection. The average total workday and garbage collection time were 8 and 5 hours, respectively. This apparently large difference (3 hours) was due to the fact that the data collection coincided with: (1) a process of outsourcing trucks, which had just recently begun, causing long delays in the trucks' arrival in the morning and (2) unusually heavy rain in Rio de Janeiro, causing traffic delays and requiring more time to cover the collection routes.

A job's physical effort can be assessed by the cardiovascular response and EE level, and both can be expressed in absolute terms and relative to either the resting or maximum values. Garbage collection is definitely strenuous, as documented by the high mean $\% \mathrm{HR}_{\text {res }}$ and IEI. Absolute HR values appear to be relatively low, considering the job's obviously high intensity, but it is impor- 
Physical and physiological characteristics of a sample of 83 garbage collectors from Rio de Janeiro, Brazil.

\begin{tabular}{lcccc}
\hline Variable & Mean & SD & Minimum & Maximum \\
\hline Age (years) & 36.8 & 8.0 & 19.7 & 63.0 \\
Body mass (kg) & 67.7 & 11.0 & 49.0 & 119.0 \\
Stature (cm) & 171.8 & 6.3 & 160.0 & 188.0 \\
Body mass index (kg.m-2) & 22.9 & 3.2 & 16.7 & 34.0 \\
Resting metabolic rate (kcal.min-1)* & 0.93 & 0.14 & 0.67 & 1.43 \\
Resting heart rate (bpm) * & 54.9 & 5.7 & 42.0 & 66.0 \\
\hline
\end{tabular}

${ }^{*} \mathrm{n}=70$.

Table 2

Total working hours (TWH), total working time (TWT), absolute (HR), percent maximal (\%HRmax), and percent reserve heart rate (\%HR res $^{\text {) }}$, energy expenditure (EE), and integrated energy index (EE/RMR - resting metabolic rate) during daily garbage collection routes for 83 garbage collectors from Rio de Janeiro, Brazil.

\begin{tabular}{|c|c|c|c|c|c|}
\hline \multirow[t]{3}{*}{ Variable } & \multicolumn{4}{|c|}{ Days of the week } & \multirow[t]{2}{*}{ Total } \\
\hline & Mondays & Tuesdays & Wednesdays & Thursdays & \\
\hline & Mean $\pm S D$ & Mean $\pm S D$ & Mean $\pm S D$ & Mean $\pm S D$ & Mean $\pm S D$ \\
\hline & $n=74$ & $\mathrm{n}=80$ & $\mathrm{n}=80$ & $\mathrm{n}=80$ & $\mathrm{n}=314$ \\
\hline $\mathrm{TWH}(\min )$ * & $562.4 \pm 160.1$ & $590.4 \pm 137.1$ & $397.7 \pm 123.2$ & $411.4 \pm 170.2$ & $489.1 \pm 171.6$ \\
\hline Heart rate $(\mathrm{HR}-\mathrm{bpm})$ & $99.4 \pm 9.6$ & $96.4 \pm 10.4$ & $97.4 \pm 11.3$ & $97.4 \pm 11.0$ & $97.6 \pm 10.6$ \\
\hline \multirow[t]{2}{*}{$\% \mathrm{HR}_{\max }$} & $54.4 \pm 5.8$ & $52.7 \pm 6.1$ & $53.3 \pm 6.6$ & $53.4 \pm 6.5$ & $53.4 \pm 6.2$ \\
\hline & $n=63$ & $n=69$ & $n=67$ & $n=67$ & $n=266$ \\
\hline TWT of energy expenditure $(\mathrm{min})$ * & $581.5 \pm 155.5$ & $600.0 \pm 133.4$ & $402.4 \pm 127.4$ & $420.6 \pm 178.4$ & $500.7 \pm 174.3$ \\
\hline$\% \mathrm{HR}_{\text {res }}$ & $34.4 \pm 7.0$ & $31.6 \pm 6.6$ & $32.8 \pm 8.7$ & $32.5 \pm 7.5$ & $32.8 \pm 7.5$ \\
\hline Energy expenditure (EE - kcal.min-1) & $4.8 \pm 1.3$ & $4.4 \pm 1.3$ & $4.5 \pm 1.6$ & $4.5 \pm 1.5$ & $4.5 \pm 1.4$ \\
\hline Total energy expenditure (kcal) * & $2814.7 \pm 1167.7 a$ & $2581.9 \pm 827.9 b$ & $1769.8 \pm 702.1 \mathrm{a}, \mathrm{b}$ & $1818.8 \pm 839.7 a, b$ & $2240.3 \pm 1001.5$ \\
\hline \multicolumn{6}{|l|}{ Integrated energy index } \\
\hline (EE/resting metabolic rate) & $4.98 \pm 1.52$ & $4.50 \pm 1.22$ & $4.71 \pm 1.69$ & $4.67 \pm 1.64$ & $4.71 \pm 1.53$ \\
\hline
\end{tabular}

*Values with the same letter are significantly different $(p<0.05)$.

$\% \mathrm{HR}_{\max }=[\mathrm{HR} /(220$-age $] \times 100$.

$\% H R_{\text {res }}=\left\{H R-H R_{\text {resting }} /\left[(220\right.\right.$-age $\left.\left.)-H R_{\text {resting }}\right]\right\} \times 100$.

tant to note that garbage collection workers in Rio de Janeiro were in good physical condition, as shown by their relatively low resting HR. Duarte 18 found similar mean daily HR (105.3bpm) in 26 garbage workers from all three shifts (morning, afternoon, and night) in the city of Florianópolis, Santa Catarina State, Brazil. Mean HR for the TWH in the present study (97.6bpm) was lower than in Dutch workers (99.5bpm) 19.

Although the empirical data are limited, work physiologists generally assume that in order to avoid fatigue, the task cannot exceed 30 to $35 \%$ of the maximum individual load for a total daily working time of 8 hours 4 . In the present study, mean $\mathrm{HR}_{\text {res }}$ values were all greater than $30 \%$ for both TWH and TGC on all the assessed days, which can be considered overload (or heavy load) according to the classification by Kemper et al. 19, who suggest that garbage collection work should not be performed at greater than $30 \%$ of maximum individual load. In an experimental study on cycling in the laboratory with 12 young adults in Taiwan, Wu and Wang 8 suggested a value of $24.5 \%$ of $\mathrm{HR}_{\text {res }}$ for an 8 -hour workday and $39 \%$ for a 4-hour day. Garbage collectors in Rio de Janeiro work far above these levels.

Workers' mean EE was high: approximately 2,800kcal during 9.7 hours on Mondays, which is approximately 5 times the resting metabolic rate (IEI). This level of EE is only found in elite 
Total time of effective garbage collection (TGC), absolute (HR), percent maximal $\left(\% H R_{\max }\right)$, and percent reserve heart rate (\%HR res), energy expenditure (EE), and integrated energy index (EE/RMR - resting metabolic rate) on daily garbage collection routes for 83 garbage collectors from Rio de Janeiro, Brazil.

\begin{tabular}{|c|c|c|c|c|c|}
\hline \multirow[t]{3}{*}{ Variable } & \multicolumn{4}{|c|}{ Days of the week } & \multirow{3}{*}{$\begin{array}{c}\text { Total } \\
\text { Mean } \pm \text { SD }\end{array}$} \\
\hline & Mondays & Tuesdays & Wednesdays & Thursdays & \\
\hline & Mean \pm SD & Mean \pm SD & Mean \pm SD & Mean \pm SD & \\
\hline & $\mathrm{n}=73$ & $n=79$ & $\mathrm{n}=78$ & $n=78$ & $\mathrm{n}=308$ \\
\hline $\mathrm{TGC}(\min )$ * & $353.0 \pm 106.6$ & $343.2 \pm 97.5$ & $250.6 \pm 82.9$ & $228.9 \pm 62.8$ & $293.1 \pm 103.9$ \\
\hline Heart rate (HR - bpm) & $105.1 \pm 11.3$ & $102.7 \pm 10.6$ & $103.8 \pm 13.2$ & $104.6 \pm 11.8$ & $104.0 \pm 11.7$ \\
\hline \multirow[t]{2}{*}{$\% \mathrm{HR}_{\max }$} & $57.6 \pm 6.7$ & $56.1 \pm 6.2$ & $56.9 \pm 7.5$ & $57.3 \pm 6.7$ & $56.9 \pm 6.8$ \\
\hline & $\mathrm{n}=62$ & $\mathrm{n}=68$ & $\mathrm{n}=65$ & $\mathrm{n}=65$ & $n=260$ \\
\hline TGC of energy expenditure $(\mathrm{min})^{\star}$ & $366.8 \pm 102.8$ & $349.3 \pm 99.5$ & $255.2 \pm 82.4$ & $231.0 \pm 64.2$ & $300.4 \pm 105.6$ \\
\hline$\% \mathrm{HR}_{\text {res }}$ & $38.6 \pm 7.8$ & $36.4 \pm 6.9$ & $37.6 \pm 9.9$ & $37.9 \pm 7.8$ & $37.6 \pm 8.2$ \\
\hline Energy expenditure (EE - kcal.min-1) & $5.5 \pm 1.4$ & $5.2 \pm 1.4$ & $5.3 \pm 1.8$ & $5.4 \pm 1.6$ & $5.4 \pm 1.6$ \\
\hline Total energy expenditure $(\mathrm{kcal})$ * & $2035.3 \pm 817.4 a$ & $1825.7 \pm 710.9 b$ & $1339.4 \pm 590.6 a, b$ & $1242.5 \pm 506.0 a, b$ & $1608.3 \pm 738.5$ \\
\hline Integrated energy index (EE/RMR) & $5.71 \pm 1.62$ & $5.41 \pm 1.37$ & $5.56 \pm 1.95$ & $5.64 \pm 1.87$ & $5.67 \pm 1.71$ \\
\hline
\end{tabular}

* Values with the same letter are significantly different $(p<0.05)$.

$\% H R_{\max }=[H R /(220$-age $] \times 100$.

$\% H R_{\text {res }}=\left\{H R-H R_{\text {resting }} /\left[(220\right.\right.$-age $\left.\left.)-H R_{\text {resting }}\right]\right\} \times 100$.

Figure 1

Relationship between integrated energy index and duration of effective garbage collection for 70 garbage collectors from Rio de Janeiro according to day of the week.
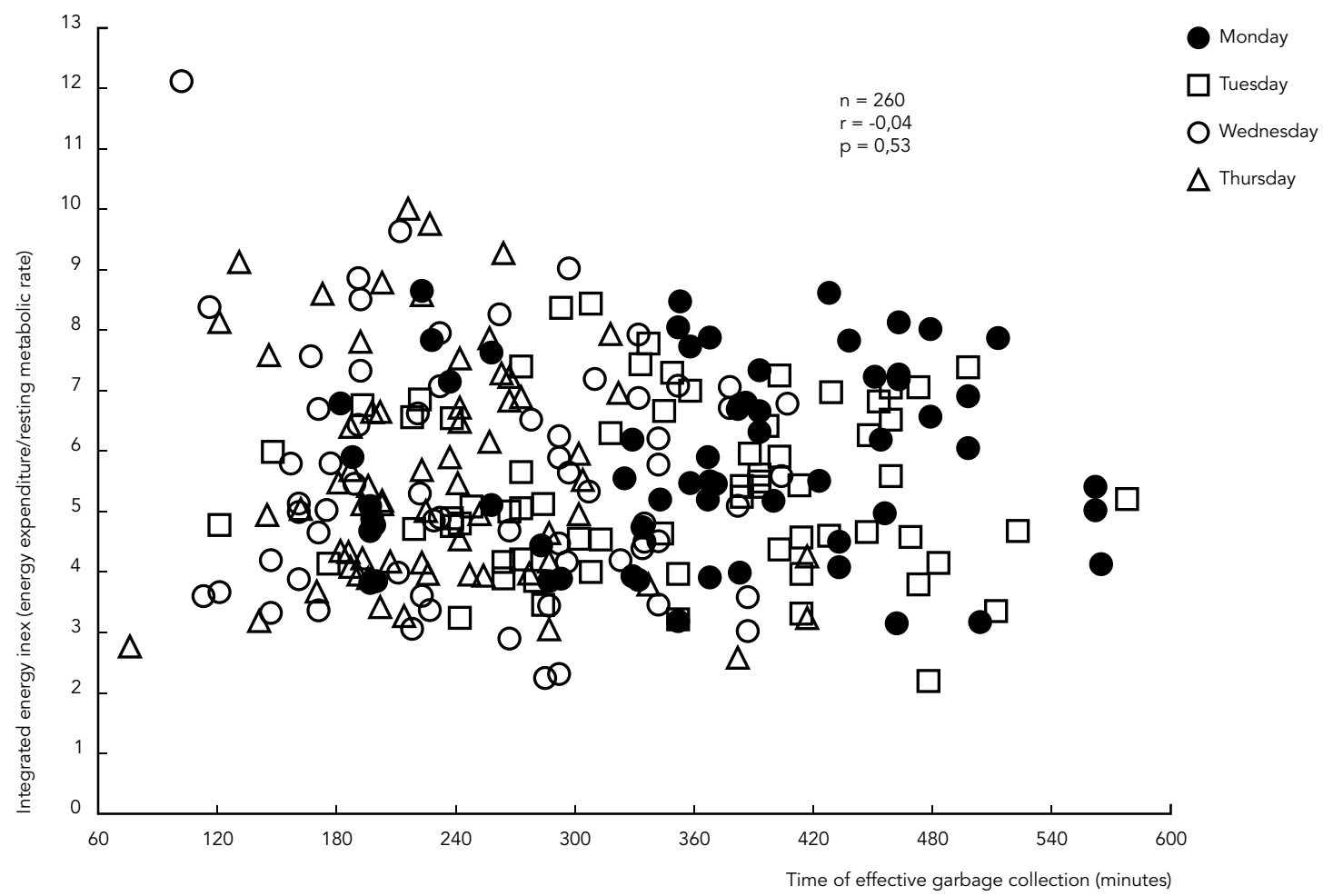
athletes during intensive training. In general, the work's intensity is indirectly related to the duration of the activity, which can be used to determine the maximum acceptable work time for a specific task ${ }^{8}$. In the specific case of garbage collection, this relation is not present due primarily to the fact that the activity is set by the speed of the truck, which determines the work pace and is approximately constant. Although the route was the same, total EE was higher on Mondays and Tuesdays than on Wednesdays and Thursdays, probably because of longer working hours resulting from greater amounts of household garbage produced on weekends.

The data obtained in garbage collectors emphasize the need for the development of appropriate classification of workload and maximum acceptable work time to be used in health-related research in Brazil 6 and in the assessment of energy needs and nutritional status of the working population, particularly in developing countries 20.

\section{Resumo}

A carga de trabalho fisiológica é utilizada para estimar a demanda física de uma tarefa na população de trabalhadores adultos; no entanto, nos países em desenvolvimento há poucos dados disponíveis sobre as diversas atividades ocupacionais. Oitenta e três trabalhadores masculinos participaram neste estudo, com o objetivo de avaliar a carga fisiológica do trabalho de coleta de lixo domiciliar no Município do Rio de Janeiro, Brasil. A freqüência cardíaca foi medida em quatro dias de trabalho consecutivos. O gasto energético foi extrapolado a partir da freqüencia cardíaca, com base em dados individuais obtidos em laboratório para a curva de freqüência cardíaca/consumo de oxigênio em 70 trabalhadores. A freqüência cardíaca média durante a coleta de lixo era 104,0 $\pm 11,7 \mathrm{bpm}$, o que representa $56,9 \pm 7,5 \%$ da freqüência cardíaca máxima. O gasto energético era de 1.608,3 $\pm 738,5 \mathrm{kcal}$ para uma média de 293, $1 \pm 103,9$ minutos de trabalho por dia. Com base em todas as medidas, o trabalho de coleta de lixo domiciliar pode ser classificado como excessivamente pesado. Os dados destacam a necessidade de se desenvolver uma classificação apropriada do trabalho, a ser utilizada em pesquisas sobre saúde do trabalhador e para definir cargas máximas de horas de trabalho em relação à carga de trabalho fisiológica, particularmente nos países em desenvolvimento.

Metabolismo Energético; Carga de Trabalho; Trabalhadores; Coleta de Resíduos Sólidos
There are relatively low-cost alternatives to reduce the workload intensity for garbage collection in Brazil and many other developing countries. Larger wheeled trash containers could be easily transported to the truck and could be hoisted and emptied mechanically, as in many developed countries. This change in the work process would reduce not only EE, but also the movements involved in handling loads: crouching, lifting weight, and torso rotation. Such operational improvements would cost relatively little in relation to the enormous benefit for workers' health and well-being, by reducing the physical demands of garbage collection. Garbage collection conditions have not changed significantly in Rio de Janeiro since 1996. Trucks are almost the same type, with some improvement in noise reduction. In the last two or three years, the use of mechanically hoisted containers has increased mainly in downtown areas and wealthier neighborhoods.

\section{Contributors}

L. A. Anjos and J. A. Ferreira planned the study and supervised the data collection. L. A. Anjos and J. J. Damião performed the data analysis. All the authors participated in writing the text.

\section{Acknowledgments}

The authors wish to thank the workers who participated in the study and the management of the Rio de Janeiro Municipal Garbage Collection Utility Company (COMLURB). Some of the heart rate monitors were provided by Proximus Tecnologia, exclusive distributor of Polar monitors in Brazil. The Indústria Brasileira de Equipamentos Médicos Desportivos Ltda (INBRAMED, Porto Alegre, Rio Grande do Sul, Brazil) provided calibration and maintenance support of the TEEM 100 calorimeter. The study was partially funded by the Brazilian National Research Council (CNPq, grants 520683/95-1, 301076/89-8, and 302952/03-9) and the PAPES I program, Oswaldo Cruz Foundation, Rio de Janeiro, Brazil. 


\section{References}

1. Ferreira JA, Anjos LA. Aspectos de saúde coletiva e ocupacional associados à gestão dos resíduos sólidos municipais. Cad Saúde Pública 2001; 17: 689-96.

2. Ferreira JA. Lixo hospitalar e domiciliar: semelhanças e diferenças. Estudo de caso no Município do Rio de Janeiro [Doctoral Dissertation]. Rio de Janeiro: Escola Nacional de Saúde Pública, Fundação Oswaldo Cruz; 1997.

3. Velloso MP. Processo de trabalho da coleta de lixo domiciliar na cidade do Rio de Janeiro: percepção e vivência dos trabalhadores [Masters Thesis]. Rio de Janeiro: Escola Nacional de Saúde Pública, Fundação Oswaldo Cruz; 1995.

4. Rodahl K. The Physiology of Work. London: Taylor \& Francis; 1989

5. Food and Agriculture Organization of the United Nations/World Health Organization. Energy and protein requirements. Geneva: World Health Organization; 1985. (Technical Report Series, 724).

6. Anjos LA, Ferreira JA. A avaliação da carga fisiológica de trabalho na legislação brasileira deve ser revista! O caso da coleta de lixo domiciliar no Rio de Janeiro. Cad Saúde Pública 2000; 16:785-90.

7. Wu H-C, Wang M-JJ. Determining the maximum acceptable work duration for high-intensity work. Eur J Appl Physiol 2001; 85:339-44.

8. Wu H-C, Wang M-JJ. Relationship between maximum acceptable work time and physical workload. Ergonomics 2002; 45:280-9.

9. Bos J, Mol E, Visser B, Frings-Dresen HW. The physical demands upon (Dutch) fire-fighters in relation to the maximum acceptable energetic workload. Ergonomics 2004; 47:446-60.

10. Wahrlich V, Anjos LA, Going SB, Lohman TG. Validation of the VO2000 calorimeter for measuring resting metabolic rate. Clin Nutr 2006; 25:687-92.
11. Weir J. New methods for calculating metabolic rate with special reference to protein metabolism. J Physiol 1949; 109:1-9.

12. Spurr GB, Prentice AM, Murgatroyd PR, Goldberg GR, Reina JC, Christman NT. Energy expenditure from minute-by-minute heart-rate recording: comparison with indirect calorimetry. Am J Clin Nutr 1988; 48:552-9

13. Wareham NJ, Hennings SJ, Prentice AM, Day NE. Feasibility of heart rate monitoring to estimate total level and pattern of energy expenditure in a population-based epidemiological study: the Ely young cohort feasibility study. Br J Nutr 1997; 78:889-900.

14. James WPT, Schofield EC. Human energy requirements: a manual for planners and nutritionists. New York: Food and Agriculture Organization of the United Nations/Oxford University Press; 1990.

15. Tukey JW. Comparing individual means in the analysis of variance. Biometrics 1949; 5:99-114.

16. Velloso MP, Santos EM, Anjos LA. Processo de trabalho e acidentes de trabalho em coletores de lixo domiciliar na cidade do Rio de Janeiro, Brasil. Cad Saúde Pública 1997; 13:693-700.

17. Brasil. Portaria MTb no. 3.214, de 8 de junho de 1978. NR-17. Diário Oficial da União 1978; 6 jul.

18. Duarte CR. Gasto energético, ingestão calórica e condições gerais de saúde de coletores de lixo de Florianópolis [Masters Thesis]. Florianópolis: Centro Tecnológico, Universidade Federal de Santa Catarina; 1998.

19. Kemper HCG, Van Aalst R, Leegwater A, Maas S, Knibbe JJ. The physical and physiological workload of refuse collectors. Ergonomics 1990; 33:1471-86.

20. Vasconcellos MTL, Anjos LA. A simplified method for assessing physical activity level values for a country or study population. Eur J Clin Nutr 2003; 57:1025-33.

Submitted on $11 / \mathrm{Jul} / 2006$

Final version resubmitted on $01 / \mathrm{Feb} / 2007$

Approved on 23/Feb/2007 